\title{
Measles virus infection as an element of differential diagnosis with other viral diseases - case reports
}

\author{
Zakażenie wirusem odry jako element diagnostyki i różnicowania z innymi chorobami \\ wirusowymi na podstawie opisu przypadków klinicznych
}

\author{
1 Department of Paediatrics, Paediatric Nephrology and Allergology, Military Institute of Medicine, Warsaw, Poland \\ ${ }^{2}$ Students'Scientific Society, Department of Paediatrics, Paediatric Nephrology and Allergology, Military Institute of Medicine, Warsaw, Poland, \\ Correspondence: Agata Wawrzyniak, Department of Paediatrics, Paediatric Nephrology and Allergology, Military Institute of Medicine, Szaserów 128,04-141 Warsaw, Poland, e-mail: awawrzyniak@wim.mil.pl
}

\begin{abstract}
Introduction: Measles is an infectious disease caused by an RNA virus of the genus Morbillivirus of the Paramyxoviridae family. It is most common in children up to the age of 15 years; however, the disease can occur at any age. The virus is transmitted through respiratory droplets. Measles presents with macular or maculopapular rash. It first appears on the head, and then spreads to the trunk and the limbs (descending nature). The rash fades in the same order it appeared, leaving skin discolourations. Measles complications occur in about $20-30 \%$ of patients, with most of them reported in children $\leq 5$ years of age and adults $>20$ years of age. Diagnosis is based on the clinical picture confirmed by serology. According to the guidelines of the World Health Organization, each suspected case should be confirmed with laboratory testing (serological or molecular diagnosis). Active immunisation is the only effective method for preventing the spread of the measles virus. In Poland, measles vaccination is one of the free mandatory vaccinations. Complete clearance of the virus is seen in the majority of immunocompetent patients. There is no specific antiviral treatment for measles. Supportive care in the form of maintaining hydration and antipyretics is used. Antimicrobial treatment should be implemented only in the case of complications. Aim: The aim of this paper is to present cases of children who developed a macular rash suggestive of measles during respiratory infection. Conclusions: Measles is an infectious disease associated with high complication rates, especially in the youngest children. Detailed differential diagnosis is needed due to its similar clinical picture to those seen in other viral rash diseases.
\end{abstract}

Keywords: measles, MMR vaccine, infectious mononucleosis, macular rash, vitamin A

Wstęp: Odra jest chorobą zakaźną, wywoływaną przez wirusa RNA z rodzaju Morbillivirus z rodziny Paramyxoviridae. Większość zachorowań rozwija się u dzieci, najczęściej do 15. roku życia, jednak choroba może wystąpić w każdym wieku. Wirus przenoszony jest drogą kropelkową. Wysypka w przebiegu odry ma charakter plamisty lub plamisto-grudkowy. Początkowo obejmuje głowę, następnie tułów i kończyny (charakter zstępujący). Ustępuje w tej samej kolejności, w jakiej się pojawiła, pozostawiając przebarwienia skórne. Powikłania w przebiegu odry występują u około $20-30 \%$ chorych; większość z nich odnotowuje się u dzieci do 5. roku życia oraz u dorosłych powyżej 20 lat. Rozpoznanie odry ustalane jest na podstawie obrazu klinicznego, potwierdzonego badaniami serologicznymi. Według wytycznych programu Światowej Organizacji Zdrowia, dotyczących eliminacji odry w Polsce, każde podejrzenie zachorowania powinno zostać potwierdzone testami laboratoryjnymi (diagnostyka serologiczna lub molekularna). W zapobieganiu rozprzestrzenianiu się wirusa odry skuteczne jest tylko uodpornienie czynne. W Polsce szczepienie przeciw odrze należy do bezpłatnych szczepień obowiązkowych. Przebieg odry u osób immunokompetentnych w większości przypadków kończy się całkowitą eliminacją wirusa. W przypadku tej choroby nie ma specyficznej terapii przeciwwirusowej. Stosuje się leczenie wspomagające w postaci nawodnienia i leków przeciwgorączkowych. Antybiotykoterapia powinna być wdrażana jedynie w przypadku wystąpienia powikłań. Cel pracy: Celem pracy jest przedstawienie przypadków dzieci z infekcją dróg oddechowych, w trakcie której pojawiła się wysypka o charakterze plamistym, mogąca sugerować rozpoznanie odry. Wnioski: Odra jest chorobą zakaźną, związaną z wysokim odsetkiem powikłań, szczególnie u najmłodszych dzieci. Z uwagi na podobieństwo obrazu klinicznego z innymi chorobami wysypkowymi o etiologii wirusowej odra wymaga przeprowadzenia szczegółowej diagnostyki różnicowej. 


\section{INTRODUCTION}

$\mathrm{M}$ easles is an infectious disease caused by an RNA virus of the genus Morbillivirus of the Paramyxoviridae family. It is a highly infectious disease responsible for 100,000 deaths/year globally, which caused 2 million deaths/per year worldwide before the widespread introduction of vaccine ${ }^{(1)}$. It is most common in children $\leq 15$ years of age; however, the disease can occur at any age. Infants $\leq 6$ months of age are immune to measles due to their serum maternal IgG antibodies.

The incidence of measles has changed over the years. According to reports from the National Institute of Public Health - National Institute of Hygiene, a total of 434 cases of measles were reported between January and March 2019, which yields an incidence of 1.13 . This is more than a 10 -fold increase compared to the same period in 2018, when there were 31 cases and an incidence of 0.08 . Furthermore, the total number of recorded cases of measles was lower in 2018 (339) compared to those recorded by mid-March 2019. According to the annual bulletin of the National Institute of Public Health - National Institute of Hygiene, which summarised the incidence of infectious diseases in 2017, there were 63 cases of measles:

- 0-9-year-olds accounted for $41.2 \%$ of cases;

- 10-14-year-olds accounted for $12.7 \%$;

- 15-19-year-olds accounted for 7.9\%;

- individuals $>19$ years of age accounted for $38.2 \%$.

The majority of patients (43) were unvaccinated ${ }^{(2)}$.

A comparison on measles incidence over 13 years in Poland is shown in Fig. 1. The virus is transmitted through respiratory droplets. It initially multiplies in the cells of respiratory mucosa and regional lymph nodes. Then, the virus travels through the bloodstream to the reticuloendothelial system, where another replication takes place and, after about 7 days, it re-enters the bloodstream and travels to the skin, conjunctiva and the mucous membranes of the nose, throat, and the respiratory tract. Four clinical phases have been distinguished for measles (Tab. 1).

Koplik's spots are a pathognomonic symptom of measles. They usually occur on day 2-3 during the catarrhal phase. They appear in the form of white lesions with a red inflammatory rim. They are found on the buccal mucosa, usually at the level of mandibular premolars and molars; Peteny's spots (small, red petechiae) may appear at the same site ${ }^{(1)}$. Measles presents with macular or maculopapular rash. It first appears on the head, and then spreads to the trunk and the limbs (descending nature). The rash fades in the same order it appeared, leaving skin discolourations.

Patients are highly infectious 4 days before rash onset and up to 4 days after the onset ${ }^{(3)}$.

Measles complications (pneumonia, bronchitis, otitis media, subglottic laryngitis, central nervous system involvement with subsequent neurological complications such as myelitis, Guillain-Barré syndrome, subacute sclerosing panencephalitis) may occur at different time points from the rash onset ${ }^{(1)}$.

Measles complications occur in about $20-30 \%$ of patients, with most of them reported in children $\leq 5$ years of age and adults $>20$ years of age ${ }^{(4)}$. The percentage of the most common complications of measles is shown in Fig. 2. Pneumonia is the most common cause of death from measles ${ }^{(1)}$.

Subacute sclerosing panencephalitis (SSPE) is the most dangerous complication of measles, the main risk factor of which is early childhood measles (1-3 years of age $)^{(5)}$. A study conducted at the University of California (USA) estimated that SSPE may develop in 1 out of 1,387 children who got measles before the age of 5 years and in 1 out of 609 children who got measles before the age of 1 year $^{(6)}$. Other risk factors include low socioeconomic status, low parental education level, no history of vaccination against measles, and more siblings ${ }^{(5)}$. SSPE usually develops several years after measles and is manifested by progressive dementia,

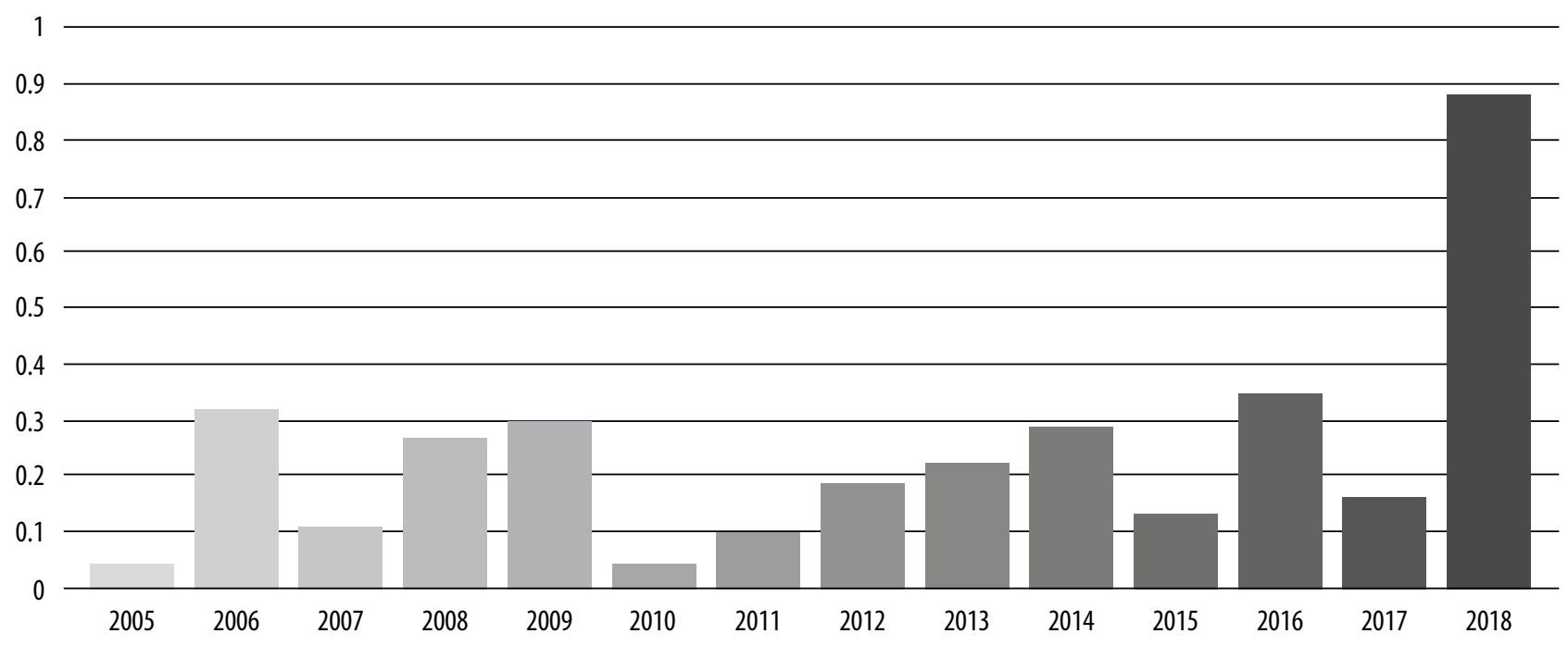

Fig. 1. Measles incidence (per 100,000 people) in the years 2005-2018 (authors' elaboration, data from the reports of infectious diseases in the National Institute of Hygiene) 


\begin{tabular}{|c|c|c|}
\hline Clinical phase & Mean duration & Characteristics and symptoms \\
\hline Incubation & $9-11$ days & $\begin{array}{l}\text { Usually asymptomatic. Possible symptoms: increased temperature, loss of appetite, deterioration of the general } \\
\text { condition }\end{array}$ \\
\hline Catarrhal (prodromal) phase & $3-4$ days & $\begin{array}{l}\text { Symptoms: } \\
\text { - high fever, }>39^{\circ} \mathrm{C} \\
\text { - } \text { - } \text { hinitis, pharyngitis or laryngitis } \\
\text { - dry barking cough } \\
\text { - conjunctivitis } \\
\text { Koplik's spots, a pathognomonic symptom of measles occurring on day 2-3 during the catarrhal phase, } \\
2-3 \text { days before rash onset }\end{array}$ \\
\hline Rash phase & $3-4$ days & $\begin{array}{l}\text { Measles rash generally appears within } 14 \text { days of exposure to the virus, } 2 \text { days after Koplik's spots. The following } \\
\text { symptoms may be observed: } \\
\text { - worsening of the patient's general condition } \\
\text { - increased body temperature up to } 40^{\circ} \mathrm{C} \\
\text { - apathy, lack of appetite, somnolence } \\
\text { - increasing cough } \\
\text { - increased heart rate, dyspnoea; possible cyanosis } \\
\text { - physical examination - auscultatory changes above lung fields indicating pneumonia or bronchitis } \\
\text { - dark red to purple maculopapules, initially involving the head - behind the ears and the forehead along } \\
\text { the hairline } \\
\text { - a descending rash, with gradual involvement of the trunk, followed by the limbs (the eruptions may be } \\
\text { confluent) } \\
\text { The patient is no longer infectious from day } 4 \text { of rash onset; therefore isolation is not needed }\end{array}$ \\
\hline Recovery phase & Several days or longer & $\begin{array}{l}\text { During this period, the body temperature drops, the rash resolves and the general condition improves. } \\
\text { Asthenia and lack of appetite may persist. Fading of the rash may be accompanied by furfuraceous epidermal } \\
\text { desquamation }\end{array}$ \\
\hline
\end{tabular}

Tab. 1. Clinical phases of measles (duration, characteristics and symptoms) $)^{(1)}$

seizures, as well as increasing muscular tone and rigidity. Death usually occurs within 2 years after the onset of symptoms. A total of 38 cases of SSPE were reported in Europe between 2007 and $2011^{(4)}$.

The diagnosis of measles is based on the clinical picture confirmed by serology. According to the guidelines of the World Health Organization, each suspected case should be confirmed with laboratory testing (serological or molecular diagnosis $)^{(7)}$. Detection of IgM antibodies specific for the virus or viral genetic material in the patient's sample are considered a positive result.

\section{Serological diagnosis}

Enzyme-linked immunosorbent assay (ELISA) detects IgM antibodies specific for measles. The antibodies occur in patient's serum within a few days of rash onset and are no longer detectable after 3-5 months. Samples should be collected 7 days after rash onset, when the levels of specific antibodies are detectable. Serum without haemolysis $(>1 \mathrm{~mL})$ is collected for IgM antibody diagnosis.

2. Molecular testing and measles virus isolation Samples should be collected 1-5 days after rash onset. After this time, the probability of detecting the measles

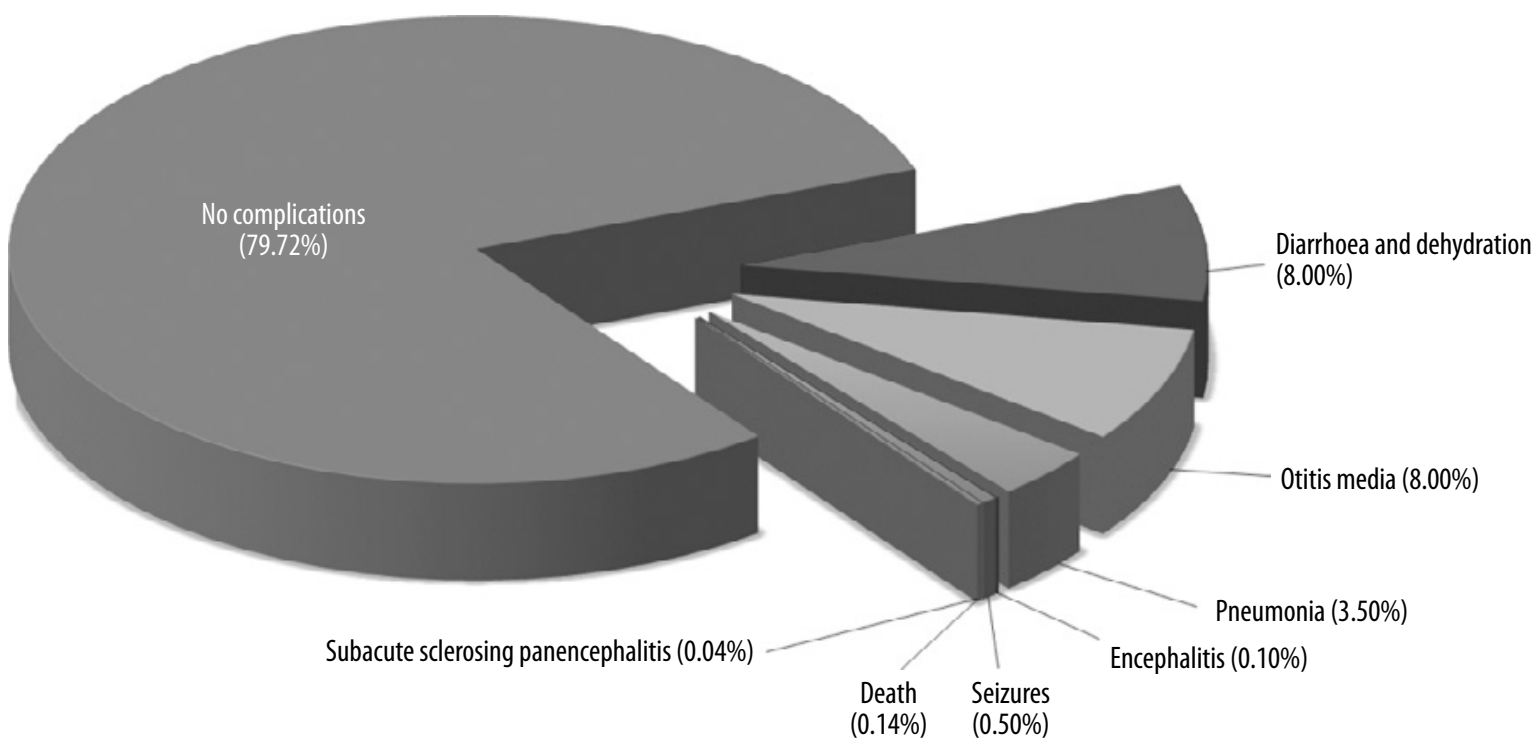

Fig. 2. The percentage of the most common complications of measles (based on the data from the National Institute of Hygiene $e^{(4)}$ ) 


\begin{tabular}{|c|c|}
\hline Age group [years] & Susceptible individuals [\%] \\
\hline $1-4$ & $\leq 15 \%$ \\
\hline $5-9$ & $\leq 10 \%$ \\
\hline $10-14$ & $\leq 5 \%$ \\
\hline$>14$ & $\leq 5 \%$ \\
\hline
\end{tabular}

Tab. 2. Limits for the percentages of people sensitive to measles virus infection in the population by age

virus genome or isolating the virus decreases dramatically. Viral genome may be isolated or detected in the pharyngeal swab (not frozen), urine (not frozen) and whole blood collected in EDTA (ethylenediaminetetraacetic acid) (not frozen).

In order to eliminate measles, it is necessary to assess the immune status of the population and monitor the percentage of vulnerable individuals in different age groups. Based on mathematical models, limits for the percentages of people susceptible to the disease were estimated to achieve herd immunity and prevent transmission of measles in the population (Tab. 2) ${ }^{(8)}$.

Active immunisation is the only effective method for preventing the spread of the measles virus. In Poland, vaccination against measles belongs to mandatory vaccinations that are free of charge. It is administered in the form of live virus vaccine against measles, mumps and rubella (combined MMR vaccine). The first dose is administered between 13 and 15 months of age, followed by the second dose at the age of 6 years ${ }^{(9)}$. Administration of two doses ensures lifelong vaccination efficacy of 98-99\%. Possible adverse effects include local reactions in the form of pain, redness, oedema and general reactions, such as mild lymphadenopathy, increased temperature, and rash.

\section{AIM}

Due to the current epidemiological situation of measles in Poland, a child presenting with macular rash requires diagnosis for Morbillivirus infection. Since a rash may occur in other clinical entities, the diagnosis should be confirmed with laboratory findings.

The aim of this paper is to present cases of children who developed a macular rash suggestive of measles during respiratory infection.

\section{CASE REPORTS}

\section{Case 1}

A 13-month-old boy was admitted to the Department of Paediatrics, Paediatric Nephrology and Allergology due to fever of up to $39.0^{\circ} \mathrm{C}$ persisting for a week, rhinitis and cough. The boy developed a non-itchy fine macular rash on the face and the trunk the day before admission. The day before reporting to hospital, the patient was examined by a paediatrician, who diagnosed pneumonia, and was put on amoxicillin with clavulanic acid (50 mg/kg/day). The child did not receive any specialist care, and was vaccinated according to the vaccination schedule.

On admission, the boy was in moderate overall condition, lethargic. Physical examination revealed a fine macular rash involving the face and the trunk. Cervical, supra/subclavian, and inguinal lymph nodes were not enlarged. Oral mucosa was moist with erosive-necrotic lesions. The tongue was not coated. The pharynx and the palatine tonsils were not inflamed. Otoscopy showed bilaterally reddened tympanic membrane with blurring of the light reflex. There was regular heart rate of $180 / \mathrm{min}$. Normal vesicular murmur over the lungs, dry rales and wheezing were present; saturation of $97 \%$. Soft abdomen non-tender on palpation; impalpable liver and spleen; normal peristalsis. No meningeal or peritoneal signs.

Laboratory tests showed low inflammatory markers [white blood cells, WBC $9.16 \times 10^{9} / \mathrm{L}, \mathrm{C}$-reactive protein, CRP $0.6 \mathrm{mg} / \mathrm{dL}$ (normal $<0.8 \mathrm{mg} / \mathrm{dL}$ ), erythrocyte sedimentation rate, ESR $37 \mathrm{~mm} / \mathrm{h}$ ]. Hepatic and renal function parameters were normal (aspartate transaminase, AST $44 \mathrm{U} / \mathrm{L}$, alanine transaminase, ALT $23 \mathrm{U} / \mathrm{L}$, creatinine $0.2 \mathrm{mg} / \mathrm{dL}$, urea $8 \mathrm{mg} / \mathrm{dL}$ ). Urinalysis showed no signs of infection. Ultrasonography of abdominal parenchymal organs showed no abnormalities. Chest radiography showed bilateral perihilar parenchymal/interstitial consolidations, particularly pronounced in the upper lung fields, as well as signs of peripheral distension of pulmonary parenchyma in the lower fields.

Bronchitis and stomatitis were diagnosed based on the clinical picture and diagnostic tests. Antibiotic therapy was continued, and symptomatic treatment was included (benzydamine, physiological saline inhalation, and clemastine at a dose of $1 \mathrm{mg} / \mathrm{kg} /$ day).

During subsequent days the rash changed into coarse macular, confluent rash with centrifugal distribution. The skin lesions gradually resolved accompanied by epidermal desquamation, leaving discolourations. A suspicion of measles was raised and serological diagnosis was performed, showing elevated IgM antibodies. Differential diagnosis for rubella and Epstein-Barr virus infection was negative.

Measles was diagnosed based on the overall clinical picture. The boy was discharged home during the recovery period.

\section{Case 2}

A 2-year-old girl was admitted to the Department of Paediatrics, Paediatric Nephrology and Allergology due to a rash persisting for 3 days, which initially occurred on the cheeks and then spread to other facial areas and the neck. The next day, the rash spread to the trunk, forearms, buttocks and lower limbs. The girl's parents noticed 
symptoms of respiratory infection, such as cough and watery nasal discharge, a week before the onset of lesions. The girl did not receive any specialist care, and was vaccinated according to the vaccination schedule.

On admission, the child was in good overall condition. A fine macular rash was present on the face, trunk, buttocks and limbs. Cervical lymph nodes were palpable, but non-tender on palpation. Mucopurulent discharge was present in the nasal atrium. Oral mucosa was moist and pink; palatine tonsils were not coated; discharge was present on the posterior pharyngeal wall. Otoscopy showed bilaterally pink tympanic membranes with light reflex. There was regular heart rate of $115 / \mathrm{min}$. Normal vesicular murmur over the lungs, no auscultatory pathologies; saturation of $95 \%$. Soft abdomen non-tender on palpation; no peritoneal symptoms; palpable liver and spleen; normal peristalsis. No meningeal signs.

Laboratory tests showed leukocytosis (WBC $\left.17.45 \times 10^{9} / \mathrm{L}\right)$; other inflammatory markers were low (CRP $0.6 \mathrm{mg} / \mathrm{dL}$, ESR $6 \mathrm{~mm} / \mathrm{h}$ ). Hypertransaminasemia was observed (AST $424 \mathrm{U} / \mathrm{L}$, ALT $699 \mathrm{U} / \mathrm{L}$ ). Renal function parameters were normal (creatinine $0.3 \mathrm{mg} / \mathrm{dL}$, urea $39 \mathrm{mg} / \mathrm{dL}$ ). Urinalysis showed no signs of infection.

Abdominal ultrasound revealed an enlarged liver $(116 \mathrm{~mm}$ in the anterior axillary line) and an enlarged spleen (length of $93 \mathrm{~mm}$ ). Both organs had normal echogenicity, with no focal lesions.

Due to hypertransaminasemia, infection with hepatotropic viruses [non-reactive anti-HCV antibodies (against hepatitis $\mathrm{C}$ virus) and anti-HAV antibodies (against hepatitis A virus), non-reactive HbsAg (hepatitis B surface antigen)], cytomegalovirus infection ( $\operatorname{IgM} 0.458, \operatorname{IgG}<0.1$ ), and toxoplasmosis ( $\operatorname{IgM} 0.263, \operatorname{IgG}<0.130$ ) were excluded. The agglutination test for mononucleosis was negative. Liver function was assessed - bilirubin levels were normal (total bilirubin $0.3 \mathrm{mg} / \mathrm{dL}$, direct bilirubin $0.1 \mathrm{mg} / \mathrm{dL}$ ); prothrombin time and INR were normal (11.7 seconds and 1.04, respectively). Signs of cholestasis were excluded [activity of alkaline phosphatase (ALP) and gamma-glutamyl transpeptidase (GGTP) was normal, i.e. $260 \mathrm{U} / \mathrm{L}$ and $52 \mathrm{U} / \mathrm{L}$, respectively].

In order to identify the aetiology of infection, the diagnosis was extended to include tests for Mycoplasma pneumoniae infection, which was excluded (low IgG and IgM antibodies), and for Epstein-Barr virus infection, with a positive IgM antibody titre in Western blot. Serology excluded measles virus infection.

Infectious mononucleosis was diagnosed based on the overall clinical picture. Drip infusions and antipyretics were used in the treatment. A descending nature of the rash with decreasing severity of lesions, clinical status improvement and resolution of clinical symptoms were observed in the following days of hospitalisation. On day 3 of hospital stay, reduced transaminase levels were observed (AST 352 U/L, ALT 385 U/L).

A comparison of laboratory findings in the described patients is shown Tab. 3 .

\begin{tabular}{|c|c|c|}
\hline Parameter & Patient 1 & Patient 2 \\
\hline WBC $\left[\times 10^{9} / L\right]$ & $9.16(4.0-10.0)$ & $17.45(4.0-10.0)$ \\
\hline Lymphocytes $\left[\times 10^{3} / \mu \mathrm{L}\right]$ & $1.60(1.9-8.0)$ & $13.20(1.9-8.0)$ \\
\hline Lymphocytes [\%] & $17.5(19.0-48.0)$ & $75.6(19.0-48.0)$ \\
\hline Neutrophils $\left[\times 10^{3} / \mu \mathrm{L}\right]$ & $6.32(0.9-4.5)$ & $3.10(0.9-4.5)$ \\
\hline Neutrophils [\%] & $69.0(40-74)$ & $17.80(40-74)$ \\
\hline Haemoglobin [g/dL] & $11.8(11.0-18.0)$ & $12.4(11.0-18.0)$ \\
\hline Platelets $\left[\times 10^{9} / \mathrm{L}\right]$ & $564(150-400)$ & $189(150-400)$ \\
\hline $\mathrm{ESR}[\mathrm{mm} / \mathrm{h}]$ & $37(0-8)$ & $6(0-8)$ \\
\hline CRP $[\mathrm{mg} / \mathrm{dL}]$ & $0.6(0.0-8)$ & $0.6(0.0-8)$ \\
\hline Procalcitonin [ng/mL] & 0.13 & 0.15 \\
\hline Creatinine $[\mathrm{mg} / \mathrm{dL}]$ & $0.2(0,7-1,2)$ & $0.3(0.7-1.2)$ \\
\hline Urea [mg/dL] & $8(17-49)$ & $8(17-49)$ \\
\hline Sodium [mmol/L] & $137(132-141)$ & $141(132-141)$ \\
\hline Potassium [mmol/L] & $4.4(3.5-5.1)$ & $4.8(3.5-5.1)$ \\
\hline AST [U/L] & $44(0-37)$ & $424(0-37)$ \\
\hline ALT [U/L] & $23(0-41)$ & $699(0-41)$ \\
\hline Agglutination test for EBV & Negative & Negative \\
\hline Test for influenza & Negative & Negative \\
\hline \multicolumn{3}{|c|}{$\begin{array}{l}\text { WBC - white blood cells; ESR - erythrocyte sedimentation rate; } \\
\text { CRP - C-reactive protein; AST - aspartate transaminase; } \\
\text { ALT - alanine transaminase; EBV - Epstein-Barr virus. }\end{array}$} \\
\hline
\end{tabular}

Tab. 3. Laboratory findings in patients 1 and 2

\section{DISCUSSION}

Recent years have witnessed an increase in the incidence of measles in countries where the virus has been almost completely eliminated from the population. The spread of measles results from the decreasing vaccination coverage. Migration and a significant increase of anti-vaccination activities significantly contribute to this phenomenon. Non-vaccinated individuals accounted for $87 \%$ of all reported cases of measles with known immunisation status in $2017^{(10)}$. Vaccination with at least 2 doses of MMR is still the most effective method for preventing further spread of measles. Unfortunately, measles vaccination coverage is lower than $95 \%$, i.e. below the level ensuring herd immunity necessary for protecting individuals who cannot be vaccinated due to their age (infants) or health status (immune deficiency), in most European Union countries ${ }^{(10)}$.

Measles bears features of an infectious disease that can be eliminated: human is the only reservoir for the virus, there is no carrier state after recovering from measles, there is no environmental contamination with the virus, and there is effective prevention in the form of vaccine. Therefore, the World Health Organization developed a strategy to eliminate measles. Rubella virus was 
also included in the programme due to the need for differentiation between infections caused by measles and rubella viruses, as well as the possibility of their elimination. Both of the described patients were assessed for anti-rubella antibodies.

Measles may pose a diagnostic challenge due to the variability of the clinical picture in the course of the disease. Other infectious diseases, such as mononucleosis in our patient, may initially produce a similar clinical picture in physical examination. Similar appearance and nature of rash may pose difficulty in the differentiation between measles and mononucleosis. Patient No. 1 developed a fine macular rash initially involving the face and the trunk, while the same type of rash first appeared on the face and the neck, and then spread to the trunk, forearms, buttocks and lower limbs in the patient No. 2. The descending nature of rash observed in both cases is typical of measles ${ }^{(1)}$. It was observed in patients with infectious mononucleosis that the fine macular rash initially occurs in about $16 \%$ of patients who received no antibiotic therapy during the disease and in up to $95 \%$ of patients treated with ampicillin ${ }^{(11)}$.

Complete clearance of measles virus is observed in the majority of immunocompetent patients. Both cellular and humoral immune components are involved in a successful immune response. A shift in the Th1/Th2 balance toward Th2-mediated response is typically seen in measles. The presence of virus-specific antibodies reduces the risk of infection, while an effective cellular response allows for the clearance of the virus from the infected body. Measles is more severe and associated with more frequent complications in children with T-lymphocyte abnormalities ${ }^{(12)}$. Furthermore, no rash is observed in the absence of an efficient cellular response ${ }^{(13)}$.

Measles virus is known to cause immunosuppression. This is associated with an increased risk of bacterial superinfections and opportunistic infections within a period of several weeks, which may extend over 2-3 years ${ }^{(14,15)}$. Immunosuppression is manifested by lymphopenia, which is observed during the rash period and associated with insufficient production of interleukin-2 $2^{(16,17)}$.

No specific antiviral treatment for measles exists. Supportive care in the form of maintaining hydration and antipyretics is used. Antibiotic therapy should be included only in the case of complications. In the 1930s, scientific reports were published about the effectiveness of intensive vitamin A therapy ${ }^{(18)}$. In subsequent years, recommendations on vitamin A supplementation in children with measles were issued ${ }^{(19)}$. Experts from the Cochrane Library performed a literature review to assess the outcomes of this type of management. Although there were no overall significant effects of vitamin A therapy on complications or mortality in children with measles, there was evidence that higher doses of vitamin A (200,000 U) significantly reduced the risk of pneumonia and general mortality in

\section{CONCLUSIONS}

Measles is a highly contagious disease associated with high complication rates, especially in the youngest children. Measles requires detailed differential diagnosis due to its similar clinical picture to those seen in other viral rash diseases.

\section{Conflict of interest}

The authors do not report any financial or personal connections with other persons or organisations, which might negatively affect the contents of this publication and/or claim authorship rights to this publication. 


\section{References}

1. Moss WJ: Measles. Lancet 2017; 390: 2490-2502.

2. Narodowy Instytut Zdrowia Publicznego - Państwowy Zakład Higieny, Główny Inspektorat Sanitarny: Choroby zakaźne i zatrucia w Polsce w 2017 roku. Available from: http://wwwold. pzh.gov.pl/oldpage/epimeld/2017/Ch_2017.pdf.

3. Strobel S, Marks SD, Smith P et al.: Choroby wieku dziecięcego. Wydawnictwo Lekarskie PZWL, Warszawa 2010.

4. Narodowy Instytut Zdrowia Publicznego: Szczepionka przeciw odrze. Available from: http://szczepienia.pzh.gov.pl/szczepionki/ odra/3/\#jak-powazne-moga-byc-objawy-odry.

5. Mekki M, Eley B, Hardie D et al.: Subacute sclerosing panencephalitis: clinical phenotype, epidemiology, and preventive interventions. Dev Med Child Neurol 2019; 61: 1139-1144.

6. Wendorf KA, Winter K, Zipprich J et al.: Subacute sclerosing panencephalitis: the devastating measles complication that might be more common than previously estimated. Clin Infect Dis 2017; 65: 226-232.

7. Zakład Wirusologii, Narodowy Instytut Zdrowia Publicznego Państwowy Zakład Higieny: Eliminacja odry/różyczki - program WHO - realizacja w Polsce - zasady - instrukcje. Warszawa 2018. Available from: https://www.pzh.gov.pl/serwisy-tematyczne/program-who-eliminacji-odry-rozyczki.

8. Janaszek-Seydlitz W: Odra w Polsce - badania seroepidemiologiczne. Available from: wwwold.pzh.gov.pl/oldpage/epimeld/ kursy/2004/Dod_1_1.pdf.

9. Dziennik Urzędowy Ministra Zdrowia: Program Szczepień Ochronnych na rok 2019. Available from: https://gis.gov.pl/wp-content/uploads/2018/01/akt.pdf.

10. Narodowy Instytut Zdrowia Publicznego: Aktualne dane epidemiologiczne o zachorowaniach na odrę w Europie w 2017 roku. Available from: https://szczepienia.pzh.gov.pl/aktualne-daneepidemiologiczne-o-zachorowaniach-odre-europie-2017-roku/.
11. Zhang L, Zhou P, Meng $Z$ et al.: Infectious mononucleosis and hepatic function. Exp Ther Med 2018; 15: 2901-2909.

12. Nanan R, Rauch A, Kämpgen E et al.: A novel sensitive approach for frequency analysis of measles virus-specific memory T-lymphocytes in healthy adults with a childhood history of natural measles. J Gen Virol 2000; 81: 1313-1319.

13. Częścik A, Trzcińska A, Siennicka J: Wirus odry - reakcje odpornościowe związane z naturalnym zakażeniem oraz odpowiedzią poszczepienną. Post Mikrobiol 2011; 50: 235-245.

14. Mina M, Metcalf CJ, de Swart RL et al.: Long-term measlesinduced immunomodulation increases overall childhood infectious disease mortality. Science 2015; 348: 694-699.

15. Griffin DE: Measles virus-induced suppression of immune responses. Immunol Rev 2010; 236: 176-189.

16. Griffin DE, Moench TR, Johnson RT et al.: Peripheral blood mononuclear cells during natural measles virus infection: cell surface phenotypes and evidence for activation. Clin Immunol Immunopathol 1986; 40: 305-312.

17. Laksono BM, Grosserichter-Wagener C, de Vries $\mathrm{RD}$ et al.: In vitro measles virus infection of human lymphocyte subsets demonstrates high susceptibility and permissiveness of both naive and memory B cells. J Virol 2018; 92. pii: e00131-18.

18. Ellison JB: Intensive vitamin therapy in measles. Br Med J 1932; 2: 708-711.

19. WHO, UNICEF: Joint WHO/UNICEF statement on vitamin A for measles. Int Nurs Rev 1988; 35: 21.

20. Huiming $Y$, Chaomin W, Meng M: Vitamin A for treating measles in children. Cochrane Database Syst Rev 2005; (4): CD001479. 